\title{
IPAR ÉS KUTATÁS: ÚJSZERŰ EGYÜTTMŰKÖDÉSI PERSPEKTÍVÁK AZ IPAR 4.0 KORSZAKÁBAN
}

\section{INDUSTRY AND RESEARCH: NEW COLLABORATIVE PERSPECTIVES IN THE INDUSTRY 4.0 ERA}

\author{
Forgó Zoltán, ${ }^{1}$ Bakos Levente ${ }^{2}$ \\ ${ }^{1}$ Sapientia Erdélyi Magyar Tudományegyetem, Marosvásárhelyi Kar, Gépészmérnöki Tanszék, \\ Marosvásárhely, Románia, zforgo@ms.sapientia.ro \\ ${ }^{2}$ Sapientia Erdélyi Magyar Tudományegyetem, Marosvásárhelyi Kar, Gépészmérnöki Tanszék, \\ Marosvásárhely, Románia, bakos@ms.sapientia.ro
}

\begin{abstract}
The paper presents some challenges of developing DIHs (Digital Innovation Hubs) based on the Industry 4.0 principles in Transylvania (Romania). DIHs have proven to be successful as knowledge transfer centers especially in information technologies, but they are still a novelty in the field of manufacturing technologies and industrial engineering in many regions. The paper presents conceptual possibilities of developing a manufacturing technology based DIH in Romania, based on cooperation among local organizations.
\end{abstract}

Keywords: Digital Innovation Hub, Industry 4.0., R\&D cooperation.

\section{Összefoglalás}

A dolgozat az Ipar 4.0 és a DIH (Digitális Innovációs Hub) fogalmi összekapcsolódási lehetőségeit taglalja regionális kontextusban. A DIH-ek bizonyítottan sikeres tudástranszferközpontok, de a gépipari technológiák esetében egyelőre még újdonságnak számítanak. Az Ipar 4.0 kifejezetten a kortárs ipar problémáira nyújt megoldásokat, szintén digitális eszközökre fektetve a hangsúlyt. A kutatás és ipar újszerű kooperációs lehetőségeit egy tervezett regionális DIH kialakításán keresztül is érzékeltetjük a dolgozatban, bemutatva egy specifikusan ipari jellegű DIH munkacsomagjait, tervezett stratégiáit.

Kulcsszavak: Digitális Innovációs Központok, Ipar 4.0, K\&F együttmüködés.

\section{Bevezetés}

Az akadémiai környezet és az ipar közötti szimbiózis ötlete közel sem újszerü, több évszázados hagyománya van. Már jóval az első ipari forradalom előtt (mai divatszóval Ipar 1.0) értelmet nyert a tudományos alapokra épített ipari tevékenység, melyhez a szaktudást és a kutatásra alapozó innovációt az akadémiai környezet szolgáltatta az ipari gyakorlat számára. Ha azonban a céhes élet gazdaságélénkítő hatására vagy az inasképzés gyakorlatára gondolunk, akkor a történelemben jóval az ipari forradalmak előtti időkben is találunk példákat arra, amit ma tudástranszfernek neveznénk. Túl a több évszázados előzményeken, immár a kiber-fizikai rendszerek, a dolgok internete (IoT - Internet of Things) világában, még mindig megoldatlan kihívás a gyártási folyamatokkal kapcsolatba hozható szervezetek közötti érdekegyeztetés, együttműködés.

Az éles piaci verseny, a geopolitikai konjunktúrák, de az ösztönös és kölcsönös segíteni akarás is újabb és újabb gazdaságélénkítő megoldásokat teremtett. Néhány éve még ismeretlen fogalmak voltak például a klaszter, az inkubátorház, a start-up cég és újabban a digitális innovációs hub, melyek olyan (ki)találmányokat fednek, amik a lehetőségek tárházát korábban elképzelhetetlen 
dimenziókba repítették. És mégis: ha megnézzük az elmúlt évek gombamód elszaporodó, majd javarészt csendben megszűnő kezdeményezéseit, megállapíthatjuk, hogy kétségtelenül vannak sikertörténetek, különlegesen az információs technológiák területén, de az általános érvényü recept még nem adott. Különösen igaz ez az EU és a világgazdaság motorját jelentő ipari gyártórendszerek esetében. A termékfejlesztés ágas-bogas folyamata, illetve a dinamikusan változó piaci környezet olyan ökoszisztémát feltételez, ahol intenzív kooperációs tevékenységek nélkül nem lehet érvényesülni, ugyanakkor a szabadalmak, a technológiai adatok biztonságos kezelése és az egyre nagyobb innovációs igény sajátos korlátokat jelentenek. A versenyképesség növeléséhez szükséges innovatív folyamatokat nem lehet - és több szempontból is nézve nem érdemes - csak a vállalat falain belül végezni.

\section{Kooperációs ökoszisztémák}

Kapcsolat a kutatási és fejlesztési (K\&F) szervezetek és a vállalatok között eddig is létezett. Az egyik részről a vállalat versenyképességének növelése, míg másik részről az üzleti szempontból értékes kutatások támogatása fontos teljesítmény-ismérv, és emiatt közös érdek volt a kezdetektől fogva. A K\&F szervezetek, értsünk ez alatt egyetemi kutatóközpontokat, illetve állami vagy vállalati konzorciumok által működtetett struktúrákat, olyan innovatív potenciált jelentenek, amelyek előnyeit kár lenne figyelmen kívül hagyni. Ezekben a partnerségekben a tudástranszfer szervezett együttműködésen keresztül jött létre. Ezek a közös érdekek mentén szerveződött olyan együttműködések, amelyek lehetővé teszik a készségek, ismeretek, technológiák átadását egy kutatószervezet és egy vállalat között. Napjainkban ennek kiemelt eszköze egy közös program, netán pályázat keretében megvalósult projekt, vagy egyszerüen egy megbízásos szerződés.

Az Ipar 4.0 korszaka erőssége abban áll, hogy lehetőség van ipari környezetben még több adatot generálni, gyüjteni és feldolgozni. Az Ipar 4.0 keretén belül megvalósulhat az okos gyár (Smart Factory): a hálózatba kötött gyártóberendezések egyre több külső és belső adathoz férnek hozzá, így a megfelelő algoritmusok segítségével nagyobb hatásfokú, nagyobb termelékenységü intelligens rendszerré alakulnak [1]. Az Ipar 4.0 immár nem kétoldalú együttmüködést feltételez, hanem a hatékony innováció érdekében kifejlesztett komplex rendszert, a magyarul kissé idegennek hangzó ökoszisztéma kialakítását jelenti [2].
Az ökoszisztémában olyan kapcsolatokat lehet kiépíteni, amelyben minden érintett fél számára elérhetővé válik egy tágabb tudásbázis, illetve ennek azonnali alkalmazása. Az ökoszisztémán belül lehetőség van anyagi erőforrások felszabadítására, átcsoportosítására és nem utolsósorban jelentős időmegtakarításra. Geopolitikai érdek, regionális, nemzeti, de akár globális érdek is, hogy ezen rendszerek által a vállalatok versenyképessége növelhető, hangsúlyosabban környezetbarát és fenntarthatóbb gazdaság valósítható meg, amelyben a kutatások/fejlesztések eredményei tágabb körében alkalmazhatókká válnak [3].

Az ökoszisztéma tagjai számára a kihívás a hasznos adatok feltárása, mely hozzásegíti őket, hogy egy termék tervezési, gyártási, használati - és hogy a körkörös gazdaság megvalósuljon - újrahasznosítási, semlegesítési folyamata megvalósuljon. Ennek az eljárásnak szerves részét képezik és kell képezzék a kutató-fejlesztő szervezetek, melyeknek - bekapcsolódva az adatáramlatba - számos lehetőségük adódik a kialakult infrastruktúra és szükségletek hatására.

A kialakított ökoszisztéma működését kétségtelenül segíti, hogy az innovációs folyamatokban jelen van az innovációkínálat (K\&F szervezetek, start-up cégek, kompetenciaközpontok, civilszervezetek és klaszterek), az innovációkereslet (nagyvállalatok, kis- és középvállalatok, start-up cégek) és az innovációt segítők (önkormányzatok, inkubátorházak, befektetési alapok, pályázatíró cégek és információs központok/Hub-ok).

Annak ellenére, hogy egy hálózat kialakítása a cél, szükség van egy koordinátorra, mely segíti a kapcsolatok kialakítását, az innovációs kereslet-kínálat egymásra találását. Az Ipar 4.0 korszakát élve, természetesen központi helyet kapnak az előbbiekben a digitális megoldások. Ennek eredményeképpen keltek életre a Digitális Innovációs Központok Európa-szerte (több mint 200 ilyen koordinátor-egység létezik), melyek régiók szintjén működnek [2].

A DIH (Digitális Innovációs Hub) központok innovációs szerepét legkönnyebben egy termék életciklusának fázisaihoz való kapcsolódási lehetőségek bemutatásán keresztül lehet érzékeltetni [4]. A termékfejlesztés fázisai olyan mérföldkövek, amelyek tulajdonképpen csatlakozási, találkozási pontok az ökoszisztéma szereplői számára. A DIH lehetővé teszi, hogy bármelyik pontban az innovációs szükségletre kerüljön egy partner, amely kielégíti ezt a szükségletet. 


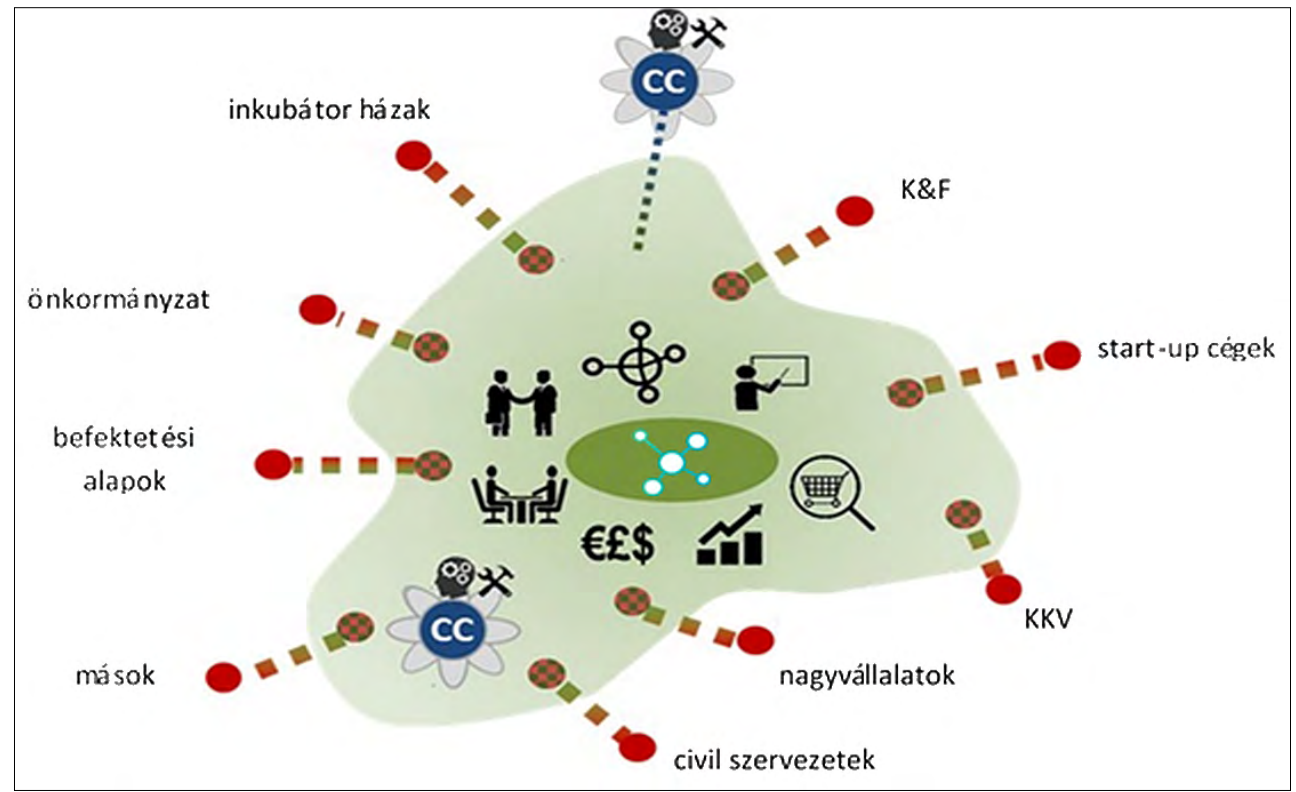

1. ábra. A DIH integratív, koordináló szerepe napjaink tudástranszfer-folyamataiban [2]

A DIH képes kell legyen, hogy esetenként infrastruktúrával is támogassa az innovációs tevékenységeket. Ilyen például a „LivingLab” (élő labor) koncepció, mely keretén belül termékek prototípusai, újszerű gyártási eljárások valósulnak meg nem ipari környezetben [4].

A továbbiakban az 1. táblázatban szintetikusan bemutatjuk az ökoszisztéma szereplői számára a rendszer által felkínált innovációs potenciál vetületeit. A táblázatban látható, hogy az ökoszisztéma egy nyer-nyer (win-win) lehetőséget jelent mind az akadémiai környezet, mind a pro-profitszereplők és jogalkotók felé. Míg ez utóbbiak megvalósulni látják a tervezett gazdaságpolitikát, addig a tudományos szervezetek kutatói valós kihívásokra keresik a választ, a vállalkozások tulajdonosai pedig a nyereségben mérhetik a modell sikerességét.

A táblázat a DIH létrehozásának előnyeit domborítja ki, ugyanakkor meg kell említenünk a kihívásokat is. Ezek részletes elemzése messze meghaladja a kézirat terjedelmi korlátait. A DIH-ek számára egyértelműen az egyik legnagyobb kihívás a bizalmi légkör megteremtése. Szisztematikus lépések és stratégiák mellett is nehéz egyes szereplőket megszólítani, bevonni az ökoszisztémába. Az ellenállás leküzdése csak akkor lehetséges, ha a megfogalmazott célok közérthetőek, a szereplők biztonságban érzik adataikat, és az eredmények viszonylag hamar jelentkeznek. A profitorientált működés egyértelmű mutatót

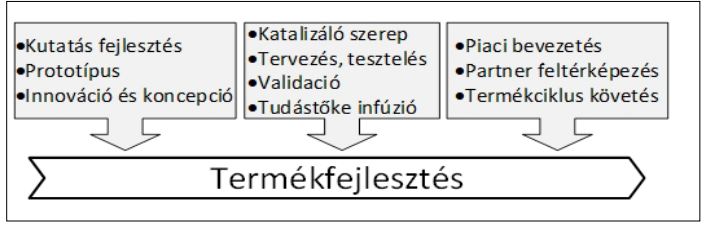

2. ábra. A DIH-katalizátor szerepe a termékfejlesztésben

1. táblázat. Előnyök a DIH-szereplők számára

\begin{tabular}{|l|l|}
\hline \multicolumn{1}{|c|}{ DIH-szereplő } & \multicolumn{1}{|c|}{ Haszon } \\
\hline $\begin{array}{l}\text { Vállalkozások } \\
\text { Nagyvállalatok }\end{array}$ & Profit \\
KKV-k & Versenyképesség \\
Star-up cégek & Innovatív termék \\
Befektetési alap & Smart factory \\
\hline K+F & CSR \\
Kutatóközpontok & Valós kihívások \\
DIH, & Valós adatok \\
Start-up cégek & Ipari léptékű fejlesztés \\
\hline Kormányzat & Finanszírozó támogatás \\
Önkormányzatok & Régiófejlesztés \\
Fejlesztési Ügynökségek & Hatékony közpénzfelhasz- \\
Kormányok & nálás \\
EU-intézmények & Munkahelyteremtés \\
\hline
\end{tabular}

határoz meg minden résztvevő számára, annak ellenére, hogy ez a szempontrendszer idegen a DIH legtöbb szereplője számára. Sem a kormányzati résztvevők, sem a civilek, sem az akadémiai szereplők számára ez nem jelent priori- 
tást, ugyanakkor a vállalkozások számára ez a szinte egyetlen lényeges szempont. Ez a kognitív disszonancia és célellentét könnyen lehet a sikertelenség egyik fő oka, akárcsak a korábbi hasonló típusú kezdeményezések sikertelenségeié. Az Ipar 4.0 annyiban hoz minőségi ugrást, hogy a szereplők a felhő technológiára alapozva aránytalanul jobban tudnak kommunikálni egymással, a Big Data korszakában korábban elképzelhetetlen nagyságrendekkel nagyobb adathalmazt lehet kezelni, az IoT pedig lehetővé teszi szinte korlátlan eszköz összekapcsolását [5]. A várható következmény az ipar számára, hogy az ökoszisztéma szereplői több partnerre kiható döntést képesek hozni emberi beavatkozás nélkül, ezáltal egy újabb szintre emelve a gyártási folyamatok vezérlését. Például közvetlenül a gyártást megelőző fázisban, ha a DIH egyik szereplője módosítást eszközöl a saját hatáskörébe tartozó termékspecifikációban, akkor a rendszer emberi beavatkozás nélkül, bizonyos keretek között, nemcsak automatikusan módosítja az adatot a partnerek adatbázisaiban, hanem belső intézkedéseket is elindít.

\section{Egy régiószintü ökoszisztéma}

Az ipari forradalmaknak akár definíciója is lehetne, hogy az ezek által kifejlesztett tudás robbanásszerűen terjed el az egész világon, s a kevésbé fejlett régiók vagy szervezetek haszonélvezőivé válnak a tudományos és műszaki világ vívmányainak. Hasonlóan, ahogy a gőzgép elterjedése az első ipari forradalom vívmányaként megváltoztatta a székelyföldi települések életét, ugyanúgy fog mindez megtörténni, valószínűleg aránytalanul nagyobb sebességgel, a negyediknek mondott ipari forradalom esetében. Tulajdonképpeni célunk az, hogy a közvetlen régióban, a pár hónapos, gyakran akár pár hetes nemzetközi gyakorlatból merítve, a térségben elérhetővé tegyük az Ipar 4.0 elvekre épülő megoldásokat, és a részt vevő szervezeteket egy müködőképes ökoszisztémává fejlesszük [6, 7] példájára. Az igen ambíciós célhoz szükséges partnerségek egy jelentős részével rendelkezünk, a kezdeményezők, a Sapientia Erdélyi Magyar Tudományegyetem Marosvásárhelyi Karának oktatói, jelentős kapcsolati tőkével rendelkeznek mindegyik fontosabb DIH-résztvevő szegmentumban (ipar, oktatás, politikum, civilszervezetek, klaszterek és a nemzetközi DIH-hálózat). Elvileg egy helyi Digitális Innovációs Központ működtetéséhez adottak a feltételek. A DIH szerepe az lenne, hogy összefogja azokat a szereplőket, melyek elengedhetetlenek a környék digitális fejlődéséhez.
Egy ökoszisztéma hatékony müködését számos tényező befolyásolja. Az első fontos sikertényező a DIH szerepének a közérthető megfogalmazása, a kifogások kezelése. Ez szükséges ahhoz, hogy bármelyik szereplő vagy partner megtalálja a helyét a rendszerben, illetve a számára előnyös együttműködési formákat. Terveink szerint ehhez fontos támogatást nyújt a testreszabott, bevált gyakorlatok bemutatása: olyan esettanulmányok közzététele, amelyek felfedik a hálózatos együttműködés szinergetikus mivoltát.

Lehetetlen, hogy egy régiószinten müködő hálózat választ tudjon adni a lokális digitális innováció minden felmerülő problémájára. Ahhoz, hogy ezt a tényt megkerüljük, csatlakozni kell a Digitális Innovációs Központok európai hálózatához és ebben aktívan részt venni. Ennek következtében részévé lehet válni és ki lehet használni azt a kollektív know-how-t, mely Európa-szerte elérhető.

A jelenleg tervezési fázisban található DIH első eredményei között említjük meg a romániai DIH-ekkel a kapcsolatfelvételt, az ezekbe való integráció lehetőségét vagy a partneri viszony kiépítését. Helyi szinten megfogalmazásra került egy olyan munkacsomagcsoport, amely újszerü nemcsak a régióban, hanem kelet-európai léptékben is. Ez teszi lehetővé részben az önálló működést vagy a zökkenőmentes integrációt a meglévő DIH-hálózatokba. A létrehozott munkacsomagokat a 3. ábra szemlélteti.

Jelenleg a különböző munkacsomagokon belüli stratégiák összehangolása zajlik. Ahhoz, hogy össze lehessen hangolni a DIH koordinációs sze-

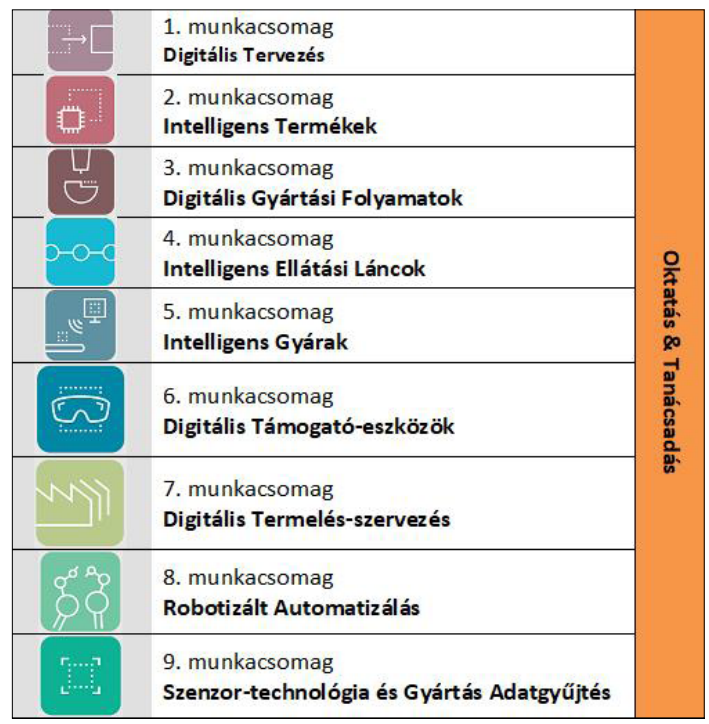

3. ábra. Létrehozott munkacsomagok ([8] alapján) 
replők munkáját, mindegyikben szükséges, hogy egy személy koordinálja a munkacsomagokat, egy személy fogja össze ezekben a tevékenységeket, hogy az innovációs kereslet-kínálat egymásra találjon, és a technológiatranszfer sikeresen megtörténjen.

A munkacsomagokon átívelő és föltétlenül szükséges tevékenység az oktatás kell legyen. $\mathrm{Az}$ innovatív digitális technológiáknak a vállalatoknál való bevezetésével nem szabad megfeledkezni a szükséges emberi erőforrásokról sem. Csak az új technológiák helyes kiszolgálása biztosítja ezek eredményes meghonosítását. A vállalatok bevonásában a két legfontosabb sikertényező valószínűleg a tudástranszferközpontok szerepének megértése-megértetése és a testreszabott mechanizmus fejlesztése a vállalatok bevonásához (know-how a know-how-hoz). Illetve nem utolsósorban kiemelt sikertényező a Nemzetközi Digitális Innovációs Központok hálózatában (Digital Innovation Hub Network) való aktív részvétel.

A kiépített ökoszisztéma a szimbiotikus kapcsolatok kialakulásához úgy járul hozzá, hogy megvalósítja és tudatosítja a közös érdekeket. Ezek közül megemlítjük a következőket:

- a vállalatok versenyképességének növelése (elsődlegesen vállalati és kormányzati érdek),

- az üzleti szempontból értékes kutatások támogatása (elsődlegesen akadémiai érdek),

-készségek, ismeretek, technológiák átadása (minden résztvevő elsődleges érdeke),

- a régiófejlődése (minden résztvevő elsődleges érdeke).

\section{Következtetések}

Egy DIH nem forradalmian új ötlet, hiszen hasonló próbálkozások az akadémiai környezet és az ipar között hagyományokra tekint vissza. Az új perspektívát az Ipar 4.0 kontextusában az jelenti, hogy partnerek aránytalanul könnyebben tudnak kommunikálni egymással, korábban elképzelhetetlen nagyságrendekkel nagyobb adathalmazt tudnak kezelni, és szinte korlátlan eszköz összekapcsolására van lehetőség. Az ökoszisztéma egy nyer-nyer (win-win) lehetőséget jelent, hiszen a jogalkotók megvalósulni látják a tervezett gazdaságpolitikát, a kutatók valós kihívásokra keresik a választ, a vállalkozások pedig a profitban mérhetik a modell sikerességét. Az ipar és kutatás újszerű együttműködési perspektívái mindenki számára adottak. Példaként egy marosvásárhelyi kezdeményezés első lépéseit mutattuk be, nevezetesen a Sapientia Erdélyi Magyar Tudományegyetem Marosvásárhelyi Kara oktatóinak kezdeti lépé- seit egy régiószintű ökoszisztéma létrehozására. Az igen ambíciós célhoz szükséges partnerségek jelentős része adott, kedvező a konjunktúra egy gépiparra összpontosító DIH létrehozására. Ez részben újszerű (a DIH-ek többségében az információtechnológia területén eredményesek), részben a már bevált gyakorlatot követő kezdeményezés. Jelenleg a tervezési fázisban található DIH első eredményei között a sajátos munkacsomagcsoport kidolgozását és a képzési tevékenység alapjainak a meghatározását említjük meg. A több mint 30 jelenlegi partnerrel folyamatosan zajlik a DIH müködési rendszerének a kidolgozása. Jelenleg a tudástranszferközpontok szerepének megértetése a fó feladat, a testreszabott együttműködési mechanizmusok kifejlesztése a know-how-hoz, minden potenciális partnerrel időigényes és egyedi feladat. A projekt népszerüsítése is elkezdődött, ennek része ez a dolgozat is.

\section{Szakirodalmi hivatkozások}

[1] Chen, B. et al.: Smart Factory of Industry 4.0: Key Technologies, Application Case and Challenges, IEEE Access. Key Technologies for Smart Factory of Industry 4.0, 6. (2018) 6505-6519.

[2] Európai Bizottság honlapja. (letöltve: 2020. december 3.)

https://s3platform.jrc.ec.europa.eu/digital-innovation-hubs-tool (letöltve: 2020. december 3.)

[3] Ustundag A., Cevikcan E.: Industry 4.0: Managing The Digital Transformation. Springer International Publishing, 2018. https://doi.org/10.1007/978-3-319-57870-5

[4] Pucihar A., Zajc I., Sernec R., Lenart G.: Living Lab as an Ecosystem for Development, Demonstration and Assessment of Autonomous Mobility Solutions. Sustainability, 11/15. (2019) 4095. https://doi.org/10.3390/su11154095

[5] Wang S., Wan J., Zhand D., Li D., Zhang C.: Towards Smart Factory for Industry 4.0: A Self-organized Multi-agent System with Big Data Based Feedback and Coordination. Computer Networks, 101/1. (2016) 158-168.

https://doi.org/10.1016/j.comnet.2015.12.017

[6] Európai Bizottság honlapja, European Digital Innovation Hubs, 2020.

https://ec.europa.eu/digital-single-market/en/ digital-innovation-hubs (letöltve: 2020. december 3.)

[7] AI DIH etworks, AI Digital Innovation Hubs Network, 2020.

https://ai-dih-network.eu (letöltve: 2020. december 3.)

[8] MADE - Manufacturing Academy of Danemark, 2020.

https://made.dk (letöltve: 2020. december 3.) 